\title{
THE PROCESSING OF SMALL ISSUES OF SECURITIES UNDER REGULATION A
}

\author{
HARVEY FranK*
}

7 HE PASSAGE of the Securities Act of 1933 marked the end of the doctrine of caveat emptor in the raising of capital through the interstate sale of private corporate securities in the United States. This was accomplished by making available to the buying public a registration statement and prospectus, as filed with the Securities and Exchange Commission, which contains substantial information about the proposed sale of a new issue of securities. These disclosures are designed to enable a prospective purchaser to make an informed investment decision. Sales by private persons who do not control the issuer are exempt from these requirements. The mechanism by which this is accomplished is Section 5 of the Securities Act of $1933 .^{1}$ Section 5 makes it a violation of the act to offer, sell or deliver a security unless a registration statement has become effective with respect to such security. A copy of the prospectus must precede or accompany the delivery of the security.

Although these safeguards are necessary, they are also expensive and time consuming. Moreover, they may create civil liability and, in some circumstances, a continuing obligation to file reports with the SEC. These burdens are inappropriate and forbidding when the funds to be raised are not large. Regulation $A,{ }^{2}$ promulgated under section 3 (b) of the act, is the Commission's solution. It is designed to facilitate the public financing of new enterprises, often in the promotional stage; small established companies seeking to expand; or large corporations making a small public offering to fulfill a special need, such as an employee stock option plan.

When a public offering of an issue of securities does not exceed

* A.B. 1951 , LI.M. 1961 New York Lniversity; LL.B. 1954 Harvard University. Member of the New York Bar. Formerly, Attorney, United States Securities and

Exchange Commission. Contributor to legal periodicals.

${ }_{4}{ }_{4}$ Stat. 74 (1933), 15 U.S.C. $\$ \$ 77 a-77$ an (195\$).

${ }^{2}{ }_{7}$ C.F.R. SS $230.25^{1-26} 3$ (Supp. 1962). 
$\$ 300,000^{3}$ and otherwise meets the standards of Regulation $A$, it is exempt from section 5 and the intertwining registration provisions of the act. Regulation $\mathrm{A}$ has evolved from a simple filing in lieu of registration through a period of minimum disclosure designed to prevent fraud ${ }^{4}$ until today's procedure is a registration in miniature. ${ }^{5}$ The necessary information is presented through a notification and offering circular filed with the Commission and available for public inspection. This offering circular serves the function of a simplified but not simple prospectus and requires full and accurate disclosure. Rule 256 of Regulation A requires that a copy of the circular must be sent to a prospective purchaser prior to or concurrently with a written offer of securities and concurrently with or prior to any confirmation of sale or partial payment of the purchase price, whichever first occurs." An offering circular need not be used in the case of a company with an earnings history which is making an offering not in excess of $\$ 50,000 .^{7}$

For the fiscal year ended June 30, 1960, I,049 notifications were filed pursuant to Regulation A for offerings of $\$ 225$ million compared with I,628 registration statements filed for offerings of $\$ 15.8$ billion. ${ }^{8}$ Since the Commission's staff devotes substantially less time to a Regulation A notification than to a comparable registration statement, the success of this program is also critical to the successful administrative processing of registration statements.

\section{Advantages of the Exemption}

\section{A. Statutory Liability}

Every person who signs a registration statement may be sued at law or in equity under Section I I of the Securities Act of 1933 if the effective registration statement contains an untrue statement or omission

${ }^{8}$ The ceiling in $\S 3$ (b) was increased from $\$ 100,000$ to $\$ 300,000$ by Act of May 15, 1945, Ch. 122, 54 Stat. 167, amending 48 Stat. 76 (1933).

'See SEC Securities Act Releases No. 3466, Mar. 6, 1952 and No. 2410, Dec. 3, 1940.

${ }^{5}$ See Illowatta Oil Company, 38 S.E.C. 720 (1958); SEC Securities Act Release No. 3663 , July $23,1956$.

- For a concise history of Regulation A, see I Loss, SEcurities Regulation 609 (2d ed. 1961) [hereinafter cited as Loss].

${ }^{7}$ Rule 257 of Regulation A, 17 C.F.R. \$ 230.257 (Supp. 1962).

${ }^{8} 26$ SEC Ann. Rep. 32, 47 (1960). The registration statements filed include 159 registration statements filed by investment companies under $\S 24(\mathrm{e})$ of the Investment Company Act of 1940 which permits registration by an amendment to a previously filed registration statement. 
of material fact. These persons include the directors of the company, the underwriter and experts, including accountants who consent to being so named in the registration statement with regard to material prepared or certified by them. There is no comparable liability for a notification.

Of course, by complying with the provisions of Regulation $A$, the prohibitions of section 5 become inapplicable. Neither the civil liability of section $12(\mathrm{I})$ of the act for recision nor the criminal penalties of section 24 of the act for offering or selling a security in violation of section 5 , can be asserted. However, in the absence of full compliance with the terms and conditions of the regulation, the Commission can suspend the exemption. Sales apparently made pursuant to an exemption would then, by the action of the SEC, have retroactively been made in violation of section 5 and would be subject to the above civil and criminal penalties. ${ }^{9}$ Thus, power of the Commission to suspend the exemption is a trap for the unwary but unless accompanied by unconscionable fraud, it is highly unlikely that the Commission would seek criminal sanctions. The constitutional problems of an ex post facto crime would therefore be avoided since an indictment would then be sought only on the grounds of fraud.

On the other hand, a purchaser should be able to assert, his section 12(r) right of recision if the Commission finds that the terms and conditions of the exemption have not been met. Here the main problem is defining the "violation" which marks the inception date of the one year statute of limitations. ${ }^{10}$ Although there is no authority on this point, a violation would seem to take place at the time of the initial offer or sale (the retroactive violation) and not when the suspension order is entered. Nevertheless, except where a filing is suspended before an offering is commenced, it is common for the statute of limitations to run on many if not all of the sales before the exemption is suspended. The right to recision under section $\mathrm{I} 2$ (I) of the act is thus illusory more often than not.

Neither the civil liability under section I2(2) of the act for the

\footnotetext{
- The Commission has not determined whether a suspension order denies an issuer the exemption $a b$ initio or from the date the order is entered. The text of the Commission's suspension orders supports the former interpretation. Any other result would make the suspension order meaningless (except as a bar to the further use of regulation A) when, as in the usual case, the suspension order is not entered until after the offering is terminated. But, for a convincing theoretical argument that the latter is usually a more appropriate result. See I Loss 628 .

${ }^{10}$ Securities Act of $1933 \$ 13$.
} 
offer, nor sale of a security by the use of false or misleading statements, nor omissions of fact made in communications to a purchaser, nor the general prohibitions against fraud in section 17 of the act are ever avoided by using the Regulation $A$ exemption.

\section{B. Periodic Reports}

Established companies which need only a small financing for a special purpose such as an employee stock option plan may find a particular advantage in Regulation $A$. If the aggregate offering price of an issue plus the aggregate value of all other securities of the same class, computed on the basis of the offering price, will exceed $\$ 2,000,000$, an issuer, as a condition of registration, must file an undertaking to furnish certain periodic reports to the Commission. ${ }^{11}$ Such an undertaking is not required for offerings exempt under Regulation A.

\section{The Filing Procedure}

The notification and offering circular under Regulation $\mathrm{A}$ are simpler to prepare and do not require as complete a disclosure as a comparable registration statement and prospectus. Furthermore, the mechanics of processing which are discussed below are less complex and usually more expeditious. Consequently, the legal, accounting and printing costs are also less and no registration fee is required..$^{12}$

Financial statements must be prepared in accordance with generally accepted accounting principles and practice but need not be certified. ${ }^{13}$ In contrast, the financial statements in a registration statement must be certified ${ }^{14}$ and conform to the more restrictive standards of the Commission's accounting rules as set forth in Regulation S-X. However, to the SEC staff, the sole criteria of generally accepted accounting principles is Regulation S-X, although they are careful not to quote the rules by name and number in comments to the public.

\footnotetext{
${ }^{12}$ Section 15 (d) of the Securities Exchange Act of 1934, 48 Stat. 88 (1934), 15 U.S.C. $\S \S 78 \mathrm{a}-78 \mathrm{bb}$ (1958).

${ }^{12}$ Rule 457 under the Securities Act, I7 C.F.R. $\$ 230.457$ (I949), sets forth a fee of $\$ 10$ per $\$ 100,000$ of securities registered, with a minimum fee of $\$ 25$.

${ }^{23}$ Item II, schedule I of the form IA to Regulation A.

An amendment to require certified statements for regulation $A$ filings was once proposed by the Commission. SEC Securities Act Release No. 3600, December 27, 1955. After considering the nature of the informational disclosure required, the limited financial information available, particularly with respect to promotional companies, 25 well as the added expense of certified statements on small businesses using the exemption, the Commission concluded not to adopt the proposal. SEC Securities Act Release No. 3783, May 7, 1957 .

16 Instructions as to Financial Statements, form S-x of Regulation $C$ under the Act.
} 
Thus the distinction required by the regulations has been whittled down by the staff into a distinction without a difference. The financial statements under Regulation $A$ must be dated within ninety days of the filing of either a notification ${ }^{\mathbf{1 5}}$ or registration statement, ${ }^{\mathbf{1 6}}$ but in a full registration statement they must also be brought current to within ninety days of the effective date, unless acceleration is granted. ${ }^{17}$

The exemption is obtained by filing four copies of the notification on form I-A, with a copy of the offering circular attached to each as an exhibit, at least ten days before the date of the proposed offering. ${ }^{18}$ The notification should be filed in the SEC regional office for the region in which the issuer's principal business operations are conducted or proposed to be conducted. ${ }^{\mathbf{1 9}}$ This latter is a requirement of venue, not jurisdiction, so if the Commission processes the file after full disclosure of the facts, it will be deemed to have waived its objections. The notification will be processed in the regional office where it was filed and where the staff has particular familiarity with local law, business problems and customs in the securities market. Counsel may often find the regional office more convenient and accessible than Washington, D.C. Although the regional office is under the supervision of the Branch of Small Issues in Washington, it has wide discretion and freedom of action.

Ten working days after the notification or the last amendment thereto is filed, the offering to which the notification relates becomes exempt even though the filing does not on its face meet all the requirements of the regulation." Although a claimant normally has the burden of proving an exemption from the act, ${ }^{21}$ Regulation $A$ does not, as it might, require the issuer to justify its exemption before it becomes effective. Following the model of a stop order procedure for full registrations, the Commission must take the initiative to suspend an exemption, before or after it becomes effective, if it has reason to

\footnotetext{
${ }^{15}$ Item $I I$, schedule $I$ of form $I A$ to Regulation $A$.

${ }^{10}$ Instructions as to Financial Statements, form S-1 of Regulation $C$ under the act.

1 The Commission provides an appropriate saving clause for the financials in the order granting acceleration. See $\S 8(a)$ of the Securities Act of $\mathbf{9} 933$.

${ }^{18}$ Rule 255 (a) of Regulation A, 17 C.F.R. $\$ 230.255$ (a) (Supp. 1962).

${ }^{20}$ Rule 255 (c), 17 C.F.R. $§ 230.255$ (c) (Supp. 1962). A special provision is therein set forth for an issuer having or proposing to have its principal business operation in Canada.

${ }^{20}$ Rule 255(a), (d) of Regulation A, 17 C.F.R. $\$ \S 230.255$ (a), (d) (Supp. $1962)$.

${ }^{21}$ See Gilligan Will \& Co. v. SEC, 267 F.2d 46x (2d Cir. 1959), cert. denied, 36r U.S. 896 (1959); SEC v. Ralston Purina Co., 346 U.S. I 19 (1953).
} 
believe that the conditions for exemption have not been observed."2: Delaying amendments are not required but the issuer will be notified not to commence its offering until informed that the staft has no further comments. Of course, it is permissible to proceed with the offering immediately after the ten day waiting period and before an effective date; but, in practice, an offering will rarely be commenced before the comments of the Commission's staff have been received and complied with by the issuer.

When the staff has no further comments, it advises the issuer that it will permit the offering to commence immediately. This effective date may be earlier than ten days from the filing of the last amendment. It is equivalent to a "no action" letter by the staff but is not within the strict regulatory scheme. However, this procedure has recently been given implicit recognition by new rule $263 .{ }^{23} \mathrm{~A}$ mechanism for acceleration does exist, ${ }^{24}$ but since it is not needed to permit the use of financials more than ninety days old at the effective date, the staff's "no comment" letter has generally replaced it. Nevertheless, the issuer and not the staff has the ultimate responsibility to see that there has been effective compliance with the regulations and the issuer will not be permitted to shift to the staff the burden of writing its offering circular. ${ }^{25}$

The privilege of the Regulation A exemption is limited. Only American and Canadian companies which have or propose to have their principal business operation in the United States or Canada are eligible. ${ }^{20}$ A clean hands doctrine also prevails. An issuer is barred if it or an affiliated issuer, predecessor, promoter, or its underwriter or an officer or principal of the issuer or underwriter has been or is subject to certain court injunctions, Commission action including the suspension of a Regulation $\mathrm{A}$ exemption, a criminal conviction relating to the distribution of securities or a post office fraud order. ${ }^{27}$ Finally, since the

${ }^{22}$ Under former Rule 233 the Commission could deny the exemption before it became effective or suspend the exemption after the effective date. When the present rules were promulgated, SEC Securities Act Release No. 3663, July 23, 1956, this - distinction in terminology was abandoned.

${ }^{28}$ SEC Securities Act Release No. 4427 (effective November 27, 1961).

${ }^{24}$ Rule $256(f)$ of Regulation A, 17 C.F.R. $\$ 230.256$ (f) (Supp. 1962).

${ }^{25}$ Texas Augello Petroleum Exploration Co., SEC Securities Act Release No. 4113 (July 21, 1959).

${ }_{26}$ Rule 252 (a) of Regulation A, 17 C.F.R. $\$ 230.252$ (a) (Supp. I 962).

${ }^{27}$ Rule 252 (c)-(e) of Regulation A, 17 C.F.R. $\$ \$ 230.252(\mathrm{c})-(\mathrm{e})$ (Supp. 1962 ). This prohibition may be waived by the Commission on a showing of good cause. Rule 252 (f) of Regulation A, I7 C.F.R. $\$ 230.252$ (f) (Supp. 1962). 
more limited information made available to the public under Regulation $A$ is not consistent with the Investment Company Act of 1940 , the exemption is not available for securities of any investment company registered or required to be registered under that statute. ${ }^{28}$

\section{Indentures}

The exemption provided by Regulation A may be used in conjunction with the exemptions provided in the Trust Indenture Act of I 934 for offerings of debt securities. An offering not in excess of $\$ 250,000$ is exempt from the requirement of using an indenture. For an offering over $\$ 250,000$ but less than $\$ 1,000,000$ an indenture must be used but it need not meet the explicit requirements of the I939 Act; ${ }^{29}$ over $\$ 1,000,000$, an indenture must conform to all the technical requirements of the 1939 Act. $^{30}$ Thus, when an offering of debentures pursuant to Regulation A exceeds $\$ 250,000$, an indenture must be used but not a "I939 Act indenture." In the interests of having one simple but general qualification procedure available, it would seem preferable to extend the exemption under the I939 Act to include all offerings pursuant to Regulation A. This can be achieved by raising the 1939 Act exemption to $\$ 300,000$.

\section{II}

\section{The Aggregate Offering Price}

The most singular feature of the section 3 (b) exemption is that the aggregate offering price of an issue during any twelve month period may not exceed $\$ 300,000$. Many of the unique problems of Regulation $A$ arise from the consequences of this requirement. Rule 254 provides in part:

The aggregate offering price of all of the following securities of the issuer, its predecessors and all of its affiliates which were incorporated or organized, or hecame affiliates of the issuer, within the past two years, shall not exceed $\$ 300,000$ :

(1) all securities of such persons presently being offered under this regulation, $\ldots$ or specified in the notification required by rule 255 as proposed to be so offered;

(2) all securities of such persons previously sold pursuant to an

\footnotetext{
${ }^{28}$ Rule 252 (b) (2) of Regulation A, 17 C.F.R. $\$ 230.252(b)$ (2) (Supp. 1962).

${ }^{20}$ Section $304(a)(8)(9)$ of the Trust Indenture Act of 1939, 53 Stat. II 49 (1939), 15 U.S.C. $\$ \S 77$ aaa-7 7 bbb (1958).

${ }^{80}$ Section 305 of the Trust Indenture Act of 1939.
} 
offering under this regulation, ... commenced within one year prior to the commencement of the proposed offering; and

(3) all securities of such persons sold in violation of section 5(a) of the Act within one year prior to the commencement of the proposed offering.

\section{A. Affiliates and Predecessors ${ }^{31}$}

To prevent an evasion of the $\$ 300,000$ ceiling through the organization of successor or affiliated companies, offerings and sales by these groups are treated as part of the issue for the purpose of computing the aggregate offering price under rule 254. But, if an affiliate was organized, incorporated, or became an affiliate at least two years prior to the commencement of the proposed offering, then its security transactions will be considered separately from those of the proposed issuer. A secondary offering is counted toward the ceiling regardless of the period of affiliation, although each person who makes a secondary offering other than on behalf of an estate is limited to an aggregate offering price of $\$ 100,000 .^{32}$

Exceptions have been created for certain industries. Thus, the aggregate offering price for an offering of interests in an unincorporated theatrical production or unincorporated real estate syndicate will not include interests offered in affiliated unincorporated theatrical productions or real estate syndicates respectively ${ }^{33}$ Under present Commission policy, an offering by such an affiliate in violation of section 5 will not be included in computing the ceiling of the issuer.

\section{B. Sales Not In Violation of Section Five}

The aggregate offering price of securities sold in violation of section 5 of the act within one year prior to the commencement of the proposed offering, whether for property or services, will be counted toward the ceiling. ${ }^{34}$ The burden of proving that these transactions are

\footnotetext{
s1 "An 'affiliate' of an issuer is a person controlling, controlled by or under common control with such issuer. ..."

"A 'predecessor' of an issuer is (i) a person the major portion of whose assets have been acquired directly or indirectly by the issuer, or (ii) a person from which the issuer acquired directly or indirectly the major portion of its assets." Rule 25x of Regulation A, 17 C.F.R. $\$ 230.251$ (Supp. 1962).

${ }^{82}$ Rule 254 (a) of Regulation A, 17 C.F.R. 230.254 (a) (Supp. 1962).

${ }^{38}$ Rule 254(d) (4), (5) of Regulation A, 17 C.F.R. $\$ \$ 230.254$ (d) (4), (5) (Supp. 1962).

${ }^{34}$ Rule 254(a) (3) of Regulation A, 17 C.F.R. $\$ 230.254$ (a) (3) (Supp. 1962). The procedure for calculating the price at which these sales will be counted towards the
} 
exempt from the prohibitions of section 5 of the act rests on the issuer. ${ }^{35}$ In satisfying this burden, the "private offering" exemption of the act is most commonly relied on. The conditions for this exemption can usually be met by the promoters of a newly formed company and by its key officers or directors provided that they obtain their securities for investment purposes and not for distribution. These persons are typically a limited group, informed about the company and with ready access to the facts which would be disclosed in a registration statement. $^{36}$ The purposes for which promoters, officers, or directors get stock and the consideration for which the stock is given will normally be substantially different from that of the subsequent public offering and the two offerings will rarely be integrated. As the offering is expanded to include friends and relatives of the original limited group, or a segment of the general public, it becomes less likely that it will be deemed a private offering, but the rules are not precise and each situation is resolved separately on the basis of its particular facts. $3 i$

An offering of stock options to a limited group of key employees will usually qualify as a private offering and if it differs from the purpose and terms of the proposed public offering, it will not be in tegrated. In such event the two offerings may be made simultaneously. On the other hand, a general offering to a large number of employees is not likely to be exempt. ${ }^{38}$

A claim of an intra-state exemption ${ }^{39}$ will almost always be denied because of integration.

The issuer may normally be recapitalized at any time, in reliance on section $3(2)(9)$ of the act, without raising any difficulties.

\section{Integration}

The purpose of limiting the exemption in section $3(\mathrm{~b})$ of the act to public issues not in excess of $\$ 300,000$ is to confine the exemption to cases of small financing. If portions of larger financing operations could be artificially segregated into several smaller issues and a separate exemption applied to each segment, the registration requirements of the

ceiling is set forth in rule 254 (b), (c) of Regulation A, 17 C.F.R. $\$ \S 230.254$ (b),

(c) (Supp. 1962).

${ }^{95}$ See cases cited note 21 supra.

${ }^{30}$ See SEC v. Ralston Purina Co., 346 U.S. 119 (1953).

${ }^{37}$ SEC Securities Act Release No. 285, Jan. 24, 1935.

${ }^{38}$ SEC v. Ralston Purina Co., 346 U.S. I19 (1953).

${ }^{80}$ Securities Exchange Act of $1933 \S_{3}(\mathrm{a})(\mathrm{iI})$. 
act could often be avoided by piling one exemption on top of another. Thus, when securities of the same class are offered on the same general terms in an uninterrupted program of distribution they will be considered by the Commission as a single issue and an exemption is valid only if it is available for the entire issue. ${ }^{40}$ If a claimed private offering or intra-state exemption is integrated with a proposed Regulation A offering, the claimed exemption would be destroyed. The value of these securities, no longer deemed exempt, would then be included as part of the aggregate offering price of the Regulation $A$ offering. If two offerings constitute separate and distinct issues, then the exemption available for each will be determined without reference to the other. A private offering will not be integrated with a subsequent offering under Regulation $A$ if the decision to go public was made after the private offering. ${ }^{41}$

Regardless of integration, sales made more than one year before the commencement of the offering or one year after the date of its commencement are not included in the ceiling. ${ }^{42}$ On the other hand, the offer and sale by an issuer of a separate and distinct issue in violation of section 5 within one year prior to the commencement of a Regulation A offering will be included in the ceiling. Such an unrelated sale immediately after the commencement of the offering is excluded from rule 254 computation.

\section{Bonus Stock}

It is customary in a public offering for the underwriter and sometimes the finder and attorneys to receive part of their compensation in securities of the issuer. It is the Commission's practice to include these securities in computing the aggregate offering price of the issue. Securities of the same class as those of the proposed public offering will be valued for this purpose at the public offering price. Options to purchase such securities or bonus securities of another class convertible into the publicly offered class of securities will also be valued at the public offering price of the underlying security. Apparently, no exemption is available, because the sales of these securities should be integrated with the public offering.

These consequences may be avoided by granting the bonus in the

\footnotetext{
${ }^{60}$ Herbert R. May \& Russell H. Phinney, 27 S.E.C. 814 (1948); Unity Gold Corporation, 3 S.E.C. 618 (1938).

${ }^{21}$ Rule 152 under the Securities Act of 1933 , 17 C.F.R. $\$ 230.152$ (1949).

" Rule 254(a) of Regulation A, 17 C.F.R. $\$ 230.254$ (a) (Supp. 1962 ).
} 
form of a personal contract which is nondivisible, nontransferable and nonexercisable until at least one year after the commencement of the public offering. Such an option would not be deemed a security for purposes of the 1933 Act until it became exercisable or until it was in fact exercised. ${ }^{43}$ In either event, the one year period during which the bonus could be considered part of the issue offered to the public for the purpose of computing the aggregate offering price in rule 254 will have passed. Naturally, the sale of the underlying securities must comply with the Securities Act of 1933 and an undertaking to that effect is usually required. ${ }^{44}$

An alternative practice has been permitted. The bonus securities are purchased prior to the commencement of the offering and effective provision is made, usually by means of an escrow agreement and an undertaking to the Commission, to assure that these securities will not be sold or otherwise disposed of until at least one year after the commencement of the public offering nor otherwise thereafter except in compliance with the Securities Act of 1933. The rationale for this procedure is muddled. Apparently keeping the securities off the public market for one year permits them to be considered as a separate and distinct issue and avoids integration. However, the sales must still be exempt from section 5 of the act or be included in the aggregate offering price under rule $254(\mathrm{a})(3)$. If the attorneys and finder take their securities for investment purposes, their purchases will be exempt as a private offering under section 4 (I) of the act. However, it is the Commission's position that an underwriter can never take securities of an issuer for investment but only for distribution. ${ }^{45}$ At the least, there is a strong presumption that such securities are taken for distribution. In such circumstances the section 4 (I) exemption should not be available. Reliance has sometimes been placed on the exclusion of preliminary negotiations between the issuer and underwriter from the broad definition of "sale" in section 2(3) of the act, but this is not convincing. This stretching of the exclusion or exemption beyond their intended seams represents an effective administrative response to the need of issuers and underwriters for more elasticity

${ }^{13}$ SEC Securities Act Release 3210 (April 9, 1947); Cf. Securities Act of 1933 $\$ 2(3)$.

"Of course, this adds nothing to the existing stautory obligations.

${ }^{45}$ The availability of the private offering exemption under $\S_{4}(1)$ of the act is a question of evidence to be determined on the facts, and so the Commission has never clearly made this a rule of law. Nevertheless, it is Commission policy. 
in the Regulation A ceiling. No one is likely to snip the threads but the problem could best be handled by an appropriate amendment to the regulations along the lines of rule 253 (c).

\section{III}

RuLE 253

Rule 253 withholds some of the advantages of Regulation A from offerings of certain promotional companies or companies without at least some recent operating profit. That is, some of the advantages of Regulation $A$ are withheld from offerings where the issuer has not had a net income from operations of the character in which the issuer intends to engage, for at least one of the last two fiscal years; or if the issuer was incorporated within one year prior to filing and has not had a net income from operations. ${ }^{48}$ A primary purpose of this provision is to prevent bailouts and limit profit from manipulation in the securities of these most speculative companies. Thus, inter alia, no securities may be sold on behalf of any person other than the issuer. ${ }^{47}$ Under subsection (c) there must be added to the aggregate offering price as computed under rule 254 :

(I) all securities issued prior to the filing of the notification, or propused to be issued, for a consideration consisting in whole or in part of assets or services and held by the person to whom issued; and

(2) all securities issued to and held by or proposed to be issued, pursuant to options or otherwise, to any director, officer or promoter of the issuer, or to an underwriter, dealer or security salesman.

No exemption in the act is applicable to this rule, but these securities need not be included if they are in escrow under an agreement with an independent escrow agent which will assure that none of these securities or any interest therein will be reoffered to the public within one year after the commencement of the offering and that any reoffering will be made in compliance with the applicable provisions of the act. A suggested form of escrow is available from the local regional office of the Commission. Its suggestions are regarded by the staff as requirements although its terms are far more restrictive than the requirements of the rule. Furthermore, these suggestions impose conditions on the transferability of the securities

${ }^{4}$ Rule 253 (a) of Regulation A, 17 C.F.R. $\$ 230.253$ (a) (Supp. 1962).

"Rule 253(d) of Regulation A, 17 C.F.R. $\$ 230.253$ (d) (Sopp. 1962). 
that go beyond any authorization in Regulation $\mathrm{A}$ or in the act. This situation represents usurpation of power by the SEC staff at its worst. ${ }^{48}$

\section{Distribution}

Between the filing and the effective date, neither a preliminary "red herring" offering circular nor a summary offering circular may be used by the issuer, underwriter or an independent organization. The underwriting syndicate, but not the selling group, may be formed. Otherwise, the same principles govern the distribution of securities whether fully registered under the act or qualified as a small issue, except that an improper distribution of the latter may cause the $\$ 300,000$ ceiling to be exceeded. In the Oklahoma-Texas Trust case, ${ }^{49}$ the Commission declared that a distribution of securities is "the entire process by which in the course of a public offering a block of securities is dispersed and ultimately comes to rest in the hands of the investing public."150 This was forcefully reiterated in the leading case of Lewisohn Copper Corp. ${ }^{.1}$ In Lewoisohn Copper, over half the issue was sold to a few broker-dealer firms for their own accounts or for the accounts of members of their families. The Commission held that these shares had not come to rest in the hands of the investing public. Many of these shares were resold to the public at prices exceeding the stated offering price. Computed at these prices, the aggregate offering price of the issue exceeded $\$ 300,000$ and the exemption was suspended. As a concomitant consequence, the statements in the offering circular as to the offering price and method of distribution were untrue statements of material fact. Furthermore, copies of the offering circular would not normally be furnished to the subsequent purchasers. The Commission, in making its decision, established prudent guides for the financial community:

The statutory limitation on the amount of securities which may be offered pursuant to the exemption provided by that section [section 3 (b) of the

${ }^{18}$ For example, the following legend must normally be stamped on the stock certificates before they are released from escrow: "No sale, offer to sell or transfer of the shares represented by this certificate shall be made unless a registration statement under the Federal Securities Act of 1933, as amended, with respect to such shares is then in effect or an exemption from the registration requirements of such Act is then in fact applicable to such shares."

${ }^{\circ \theta_{2}}$ S.E.C. $76_{4}$ (1937), aff'd, 100 F.2d 888 (10th Cir. 1939).

${ }^{80}{ }_{2}$ S.E.C. $764,769-70$ (1957).

${ }^{8 x}$ SEC Securities Act Release No. 3907 (March 18, 1958). 
act]. would be meaningless if a substantial part of an issue stated to be in the aggregate amount of $\$ 300,000$ could be sold as in this case to a relatively small number of broker-dealers and persons associated with them who purchase such shares with a view to reselling and who in turn resell to the general investing public at prices higher than the stated offering price. Such a procedure is tantamount to the organization of a selling group. Where such a method of distribution, which carries with it a probability of resales to the general investing public, is employed by an issuer or underwriter and resales are made at prices which result in the $\$ 300,000$ limitation being exceeded, it cannot be claimed that the offering is entitled to the Regulation A exemption. ${ }^{52}$

The issuer must take precaution to guard against unlawful practices by the underwriter, for he will be held responsible for the underwriter's actions. Even if the issuer has no reason to believe that the rules are being violated and has used reasonable efforts and diligence to maintain control of the underwriter and did not participate in the unlawful practices, nevertheless, there will not be grounds for an order vacating the suspension of the exemption. ${ }^{53}$

\section{V}

\section{Suspension}

The Commission's primary tool in enforcing complaince with Regulation $A$ is its power, pursuant to rule $26 \mathrm{I}$, to suspend the exemption either before or after the offering is commenced. ${ }^{\mathbf{5}}$ Aside from losing the exemption for the issue in question, a suspension will bar the use of Regulation A for five years to the issuer or its affliates or to any underwriting in which the underwriter participates as an underwriter. ${ }^{\text {b5 }}$ An order temporarily suspending the exemption may be entered by the Commission at any time that it has reason to believe that there are facts to support such an order, and it is based on a recommendation by the staff. The full grounds for suspension are set forth in rule

${ }^{*}$ Ibid.

${ }^{83}$ See Utah-Wyoming Atomics Corporation, 36 S.E.C. 454 (2955).

${ }^{84}$ See note 22 supra. In the fiscal year 1960, the Commission entered 75 orders temporarily suspending the exemption, 5 were vacated, 35 requested a hearing of which 6 withdrew their request and 8 were pending at the end of fiscal 1960. 26 SEC Ann. Rep. 48 (1960).

${ }^{88}$ Rule 252 (c) (2), (e)(2) of Regulation A, 17 C.F.R. $\S 230.252(c)(2),(e)(2)$ (Supp. 1962). The Commission may suspend an exemption, not as a sanction but to make the registration provisions of the act applicable to the remainder of the offering and future offerings for itself and its affiliates for a specified time. Selevision Western, Inc., 37 S.E.C. 411 (1956). 
$26 \mathrm{r}$, but in general a suspension order may be entered if the terms and conditions of the regulation have not been complied with; there are false or misleading statements or omissions in the notification, offering circular or sales literature; or there has been a violation of the fraud provisions of section $x_{7}$ of the act. A hearing may be requested by the issuer within thirty business days after the temporary order has been entered or it will become permanent. At this hearing the Commission will not assess the business potentialities of the issuer in making its determination, ${ }^{56}$ although the Branch of Small Issues sometimes considers this a basis for not recommending a suspension to the Commission. After the hearing, the Commission will either vacate the order or enter an order permanently suspending the exemption.

\section{VI}

\section{Conclusion}

Regulation A provides a relatively rapid, inexpensive filing procedure while placing adequate information before the investing public. The danger lies in the grossly speculative nature of many of the issues, freeloading and the relative ease with which a small issue with a cheap price and relatively short supply of stock can be manipulated. These problems are not peculiar to Regulation $A$ and do not arise from any particular defect in the regulation or its administration. Instead, they are inherent in the size of the issues and the failure of purchasers to read an offering circular before, or even after, they buy. The abandonment of Regulation A would reduce the number of these abuses only as it cut back the number of such offerings. In fact, the restrictions on bonus stock generally eliminate a quick bailout on a short term market swing generally available to an underwriter and others in full registration.

The ability of small industrial companies to attract public venture capital is an important stimulus to innovation and diversity in our economy. While much room remains for improvement, the present Regulation A effectively serves the function for which it was designed.

\footnotetext{
${ }^{80}$ Arizona Aviation \& Missile Corporation, SEC Securities Act Release No. 4135 (August 31, 1959).
} 